\title{
Antioxidant and Antimicrobial Activities of the Extracts from Different Garcinia Species
}

\author{
Nguyen Hoai Nguyen $\mathbb{D}^{1},{ }^{1}$ Minh Tan Nguyen $\mathbb{D}^{2},{ }^{2}$ Hiep Dinh Nguyen, ${ }^{3}$ Phuoc Dien Pham, ${ }^{3}$ \\ Ut Dong Thach, ${ }^{3}$ Binh T. D. Trinh, ${ }^{4,5}$ Ly T. T. Nguyen, ${ }^{4,5}$ Son V. Dang, ${ }^{6}$ Anh Thu Do $\mathbb{D}^{7}$ \\ and Bich Hang Do $\mathbb{D}^{3}$
}

\author{
${ }^{1}$ Faculty of Biotechnology, Ho Chi Minh City Open University, Ho Chi Minh City, Vietnam \\ ${ }^{2}$ NTT Hi-Tech Institute, Nguyen Tat Thanh University, Ho Chi Minh City, Vietnam \\ ${ }^{3}$ Faculty of Pharmacy, Ton Duc Thang University, Ho Chi Minh City, Vietnam \\ ${ }^{4}$ Faculty of Chemistry, University of Science VNU-HCM, 227 Nguyen Van Cu, Ho Chi Minh City, Vietnam \\ ${ }^{5}$ Vietnam National University Ho Chi Minh City, Ho Chi Minh City, Vietnam \\ ${ }^{6}$ Institute of Tropical Biology, VAST, 85 Tran Quoc Toan, Ho Chi Minh City, Vietnam \\ ${ }^{7}$ English Faculty, Foreign Trade University-Ho Chi Minh City Campus, Ho Chi Minh City, Vietnam
}

Correspondence should be addressed to Bich Hang Do; dobichhang@tdtu.edu.vn

Received 26 February 2021; Accepted 9 June 2021; Published 21 June 2021

Academic Editor: Junghyun Kim

Copyright (C) 2021 Nguyen Hoai Nguyen et al. This is an open access article distributed under the Creative Commons Attribution License, which permits unrestricted use, distribution, and reproduction in any medium, provided the original work is properly cited.

\begin{abstract}
Background. Garcinia is a large genus which has promising bioactivities. However, the properties of many Garcinia species have not been investigated thoroughly. Aim. To determine the antioxidant and antimicrobial capabilities of the extracts from different Garcinia species. Methodology. Six Garcinia species, including Garcinia fusca, Garcinia hopii, Garcinia planchonii, Garcinia nigrolineata, Garcinia gaudichaudii, and Garcinia tinctoria were extracted using $n$-hexane, ethyl acetate, and methanol, producing $n$-hexane extract (HE), ethyl acetate extract (EAE), and methanol extract (ME). After that, the total polyphenol content was evaluated using Folin-Ciocalteu assay. DPPH, hydroxyl radical scavenging, and total antioxidant capacity assays were performed to test the antioxidant activity. Subsequently, the antimicrobial activities against Gram-positive (Staphylococcus aureus, Bacillus subtilis) and Gram-negative (Escherichia coli, Pseudomonas aeruginosa) bacterial strains were assessed using Kirby Bauer and the broth microdilution methods. Results. Many Garcinia extracts contained high total polyphenol content consisting of ME of G. hopii ad G. tinctoria, and EAE of G. planchonii and G. tinctoria. The EAE of G. tinctoria showed effective antioxidant capacity $\left(\mathrm{IC}_{50}=1.5 \mu \mathrm{g} / \mathrm{mL}\right)$. Additionally, the EAE of $G$. gaudichaudii was effective against Gram-positive bacteria with minimal inhibition concentration (MIC) of $15.625-25 \mu \mathrm{g} / \mathrm{mL}$ whereas ME of $G$. planchonii was effective against both Gram-positive bacteria $(\mathrm{MIC}=160 \mu \mathrm{g} / \mathrm{mL})$ and Gram-negative bacteria $(\mathrm{MIC}=75 \mu \mathrm{g} / \mathrm{mL})$. Conclusion. Several extracts of Garcinia species demonstrated valuable antioxidant and antimicrobial properties.
\end{abstract}

\section{Introduction}

The genus Garcinia belonging to the Clusiaceae family is a sizable group of plants. It consists of over 200 species mainly distributing in the world's tropics, chiefly in Asia, Africa, and Polynesia. They are evergreen polygamous trees, shrubs, and herbs. Many species of Garcinia have been proven highly nutritious and utilized as food, supplemental products, and nutritional supplements. The most widely studied is G. mangostana or mangosteen, the extract of which contains a high amount of isoprenylated xanthones exerting anticancer, analgesic, neuroprotective, antidiabetic, and hypolipidemic effects [1]. Another species of Garcinia is G. cambogia, whose extract containing high hydroxycitric acid which is used as a weight-loss supplement by reducing fat accumulation [2, 3]. Moreover, the supplement of 
G. cambogia also helps to reduce inflammation and glucose intolerance [4]. Other species of Garcinia have also been investigated; those include $G$. celebica, G. nigrolineata, G. cowa, G. indica, G. schomburgkiana Pierre., G. preussii, and G. fusca [1,5-8]. Specifically, the extract G. celebica leaves exerted anticancer activities by enhancing apoptosis on MCF-7 human breast cancer cell lines [5]. In addition, the leaf extract of $G$. celebica and extracted compound, catechin, exhibited antiproliferation on Plasmodium falciparum by oxidative stress induction [9]. Likewise, xanthones collected from the root of G. fusca inhibited $\alpha$-glucosidase, making it a candidate for antidiabetes [10] whereas quinone and xanthones isolated from the extracts of $G$. nigrolineata show high antibacterial activity $[6,11,12]$. Another outstanding feature is that the fruit rind of $G$. indica possesses both antioxidant and hepatoprotective properties [13].

In modern societies, the increasing level of stress, air pollution, food toxicity, and so forth causes reactive oxygen species production, leading to DNA damage, which gives rise to several chronic and degenerative diseases such as antiaging, anti-inflammatory, antiatherosclerosis, and anticancer $[14,15]$. Antioxidants are substances that inhibit the initiation or propagation of oxidative chain reactions, scavenge free radicals, quench singlet oxygen, and reducing agents, resulting in the reduction of oxidative stress for the cell $[16,17]$. Therefore, finding substances and extracts with high antioxidant capacity is a crucial issue.

The plan is believed to be a crucial source of natural antioxiadants and antimicrobial activity. Firstly, these natural antioxidants, especially polyphenols and carotenoids, are capable of scavenging free radicals or stabilizing free reactive oxygen species to prevent oxidative stress within the cell environment. Studies demonstrated that several Garcinia species possessed the high antioxidant ability, including G. mangostana L., G. indica, G. cambogia, $G$. atroviridis $[13,18-21]$. The antioxidant activity of these extracts has been applied to treat various related diseases. Secondly, with regard to antimicrobial activity, the plant extracts might be derived from phenolics, terpenoids, essential oil, alkaloids, lectins, polypeptides, and polyacetylenes [22-24]. Several Garcinia has demonstrated the capability of exhibiting antimicrobial activity. For instance, the extracts of G. cambogia leaves and G. indica fruits showed interesting anthelmintic and antibacterial activities against earthworm and Gram-positive bacteria, respectively [25, 26].

In Vietnam, there are several Garcinia species grown wildly, of which their bioactivities have not been clearly elucidated. In this study, six Garcinia species including G. fusca, G. hopii, G. planchonii, G. nigrolineata, G. gaudichaudii, and G. tinctoria were collected and extracted using different solvents. Subsequently, the polyphenolic content, the antioxidation, and the antimicrobial capability of the extracts were examined.

\section{Materials and Methods}

2.1. Materials. The plant samples were collected from different Vietnam provinces and identified by Dr. Son V. Dang, the curator of the VNM Herbarium, Institute of Tropical
Biology, Ho Chi Minh City, Vietnam. Voucher specimens were deposited in the Natural Product and Medicinal Chemistry Lab, University of Science, VNU-HCM. Data of sample collection are shown in Table 1.

Solvents such as $n$-hexane, ethyl acetate, methanol, and dimethyl sulfoxide (DMSO) were purchased from SigmaAldrich (St Louis, MO, USA). Folin-Ciocalteu and 2, 2diphenyl-1-picrylhydrazyl (DPPH) were obtained from Sigma-Aldrich (St Louis, MO, USA). Mueller-Hinton Broth and Mueller-Hinton Agar were acquired from Thermo Fisher Scientific (Massachusetts, USA).

\subsection{Methods}

2.2.1. The Preparation of Garcinia Extracts. One hundred grams of each plant material was air-dried, grounded, and then subjected to Soxhlet extraction with $350 \mathrm{~mL}$ of methanol to yield a concentrated solution. Methanol was then removed under reduced pressure using a rotary evaporator system to obtain an initial extract. The extract was then subjected to solid-phase extraction, where the sample was thoroughly washed with $5 \mathrm{~L}$ of $n$-hexane, $10 \mathrm{~L}$ of ethyl acetate, and $10 \mathrm{~L}$ of methanol, respectively. After concentration, $n$-hexane extract (HE), ethyl acetate extract (EAE), and methanol extract (ME) were attained. Data of extract preparation are described in Table 1.

2.2.2. The Measurement of Total Phenolic Content. Total phenolic content (TPC) of Garcinia extracts was determined using Folin-Ciocalteu assay, following the protocol of Singleton et al. [27]. In particular, $800 \mu \mathrm{L}$ of HE, EAE, and $\mathrm{ME}$ at the concentration of $50 \mu \mathrm{g} / \mathrm{mL}$ were mixed with $100 \mu \mathrm{L}$ of Folin-Ciocalteu reagent (diluted 4 times), followed by an addition of $100 \mu \mathrm{L}$ of $20 \%(\mathrm{w} / \mathrm{v})$ sodium carbonate. After being mixed carefully, the mixture was kept in the dark at room temperature for 30 mins. The absorbance of these samples was measured at $760 \mathrm{~nm}$ using a spectrophotometer (Thermo Scientific, Massachusetts, USA). Gallic acid was used as a reference. Gallic acid at different concentrations $(200,100,50,25,12.5,6.25,3.125$, and $1.56 \mu \mathrm{g} / \mathrm{mL})$ was applied following the aforementioned protocol to prepare a standard curve. TPC was expressed as milligrams of gallic acid equivalent (GAE) per gram of the dry extract.

2.2.3. DPPH Assay. The free radical scavenging activity of the extracts was evaluated using DPPH assay according to the method described by Shen et al. [28]. The extracts were diluted in $0.1 \mathrm{mM}$ DMSO to various concentrations from 0 to $200 \mu \mathrm{g} / \mathrm{mL}$. $0.5 \mathrm{~mL}$ of the extracted was added to $1.5 \mathrm{~mL}$ of $0.1 \mathrm{mM}$ DPPH which was dissolved completely in methanol. The mixtures were shaken vigorously and incubated in the dark at room temperature for 30 mins. Then, the absorbance was measured at $517 \mathrm{~nm}$ using a spectrophotometer. Ascorbic acid was used as a positive control. The capability of scavenging the DPPH radical was calculated using the following formula: 
TABLE 1: Summarization of sample collection and extract preparation of various species of genus Garcinia.

\begin{tabular}{|c|c|c|c|c|c|}
\hline Garcinia species & Collecting part & Collecting region & Collecting date & \multicolumn{2}{|c|}{ Weight of extracts (g) } \\
\hline G. fusca & Roots & Dong Nai & March 2015 & $\begin{array}{c}\text { Hexane } \\
\text { Ethyl acetate } \\
\text { Methanol }\end{array}$ & $\begin{array}{l}2.90 \\
6.67 \\
4.97 \\
\end{array}$ \\
\hline G. hopii & $\begin{array}{l}\text { Stems } \\
\text { Leaves }\end{array}$ & Khanh Hoa & April 2015 & $\begin{array}{c}\text { Hexane } \\
\text { Ethyl acetate } \\
\text { Methanol }\end{array}$ & $\begin{array}{l}0.64 \\
0.97 \\
0.82 \\
\end{array}$ \\
\hline G. planchonii & Barks & Khanh Hoa & April 2015 & $\begin{array}{c}\text { Hexane } \\
\text { Ethyl acetate } \\
\text { Methanol }\end{array}$ & $\begin{array}{l}10.19 \\
9.00 \\
5.61 \\
\end{array}$ \\
\hline G. nigrolineata & Barks & Dong Nai & March 2016 & $\begin{array}{c}\text { Hexane } \\
\text { Ethyl acetate } \\
\text { Methanol }\end{array}$ & $\begin{array}{l}7.33 \\
1.32 \\
3.37 \\
\end{array}$ \\
\hline G. gaudichaudii & Barks & Phu Quoc & May 2016 & $\begin{array}{c}\text { Hexane } \\
\text { Ethyl acetate } \\
\text { Methanol }\end{array}$ & $\begin{array}{l}4.86 \\
0.78 \\
2.21 \\
\end{array}$ \\
\hline G. tinctoria & Barks & Dong Nai & May 2016 & $\begin{array}{c}\text { Hexane } \\
\text { Ethyl acetate } \\
\text { Methanol }\end{array}$ & $\begin{array}{l}9.26 \\
3.61 \\
3.35 \\
\end{array}$ \\
\hline
\end{tabular}

$$
\% \text { inhibition }(\% I)=\left\{\left(\frac{A_{0}-A_{1}}{A_{0}}\right) * 100\right\} \text {. }
$$

$A_{0}$ is the absorbance of the control reaction and $A_{1}$ is the absorbance in the presence of the extracts or positive control.

\subsubsection{Determination of Hydroxyl Radical Scavenging Assay.} The hydroxyl radical scavenging activity of the extracts was assessed according to the protocol of Klein et al. [29]. $90 \mu \mathrm{L}$ of the extracts with the concentrations ranging from 0 to $1,000 \mu \mathrm{g} / \mathrm{mL}$ was supplemented with $45 \mu \mathrm{L}$ of $8 \mathrm{mM}$ FeS$\mathrm{O}_{4} .7 \mathrm{H}_{2} \mathrm{O}, 63 \mu \mathrm{L}$ of $5.7 \mathrm{mM}$ salicylic acid, and $72 \mu \mathrm{L}$ of $6 \mathrm{mM} \mathrm{H}_{2} \mathrm{O}_{2}$. The mixture was incubated at $37^{\circ} \mathrm{C}$ for $30 \mathrm{mins}$ before being applied onto a spectrophotometer to measure the absorbance at $562 \mathrm{~nm}$. Ascorbic acid was used as a positive control. The percentage of the hydroxyl scavenging activity was calculated using the following formula:

$$
\% \mathrm{OH}-\text { scavenging activity }=\left[1-\left(\frac{A_{\text {sample }}-A_{\text {sample blank }}}{A_{\text {control }}-A_{\text {control blank }}}\right)\right] \times 100
$$

$A_{\text {sample blank }}$ or $A_{\text {controlblank }}$ is the absorbance value of sample or control without salicylic acid.

$A_{\text {sample }}$ or $A_{\text {control }}$ is the absorbance value of the sample or control with salicylic acid.

2.2.5. Determination of Total Antioxidant. The total antioxidant capacity (TAC) of the extracts was estimated following the method reported by Wan C. et al. [30]. $0.1 \mathrm{~mL}$ of the extracts at the concentration of $200 \mu \mathrm{g} / \mathrm{mL}$ was added with $0.9 \mathrm{~mL}$ of $0.6 \mathrm{~mol} / \mathrm{L}$ sulfuric acid, $28 \mathrm{mmol} / \mathrm{L}$ sodium phosphate, and $4 \mathrm{mmol} / \mathrm{L}$ ammonium molybdate. The mixture was incubated at $90^{\circ} \mathrm{C}$ for 90 mins using a water bath. After cooling down to room temperature, the samples were centrifuged at $5000 \mathrm{rpm}$ for $5 \mathrm{mins}$ to obtain the supernatants. The absorbance of the supernatants was measured at $695 \mathrm{~nm}$ using a spectrophotometer. Ascorbic acid at a $0-125 \mu \mathrm{g} / \mathrm{mL}$ concentration was used to prepare a standard curve. The activity of extracts was expressed as ascorbic acid equivalent (AAE) mg per $g$ of the extracts.
2.2.6. Kirby Bauer Assay. The antibacterial activity of the extracts was tested using Kirby Bauer diffusion method [31]. Briefly, the extract at a concentration of $100 \mathrm{mg} / \mathrm{mL}$ was prepared in DMSO. Different bacteria including Grampositive (Staphylococcus aureus, Bacillus subtilis) and Gramnegative (E. coli, Pseudomonas aeruginosa) were cultured in Mueller-Hinton broth for $3 \mathrm{~h}$ at $37^{\circ} \mathrm{C}, 200 \mathrm{rpm}$ shaking. The cell density was determined by measuring optical density at $600 \mathrm{~nm}$ using spectrophotometer. The bacterial suspensions were diluted to $10^{8} \mathrm{CFU} / \mathrm{mL}$, then spread on the surface of Mueller-Hinton agar plates using sterile swabs. $6 \mathrm{~mm} \varnothing$ wells were created and $20 \mu \mathrm{L}$ the extracts were then supplemented into each well. The plates were incubated at $4^{\circ} \mathrm{C}$ for $2 \mathrm{~h}$ to allow the diffusion of the active compounds in the medium. The plates were incubated at $37^{\circ} \mathrm{C}$ for $16-18 \mathrm{~h}$. Plates treated with $20 \mu \mathrm{L}$ DMSO were used as negative controls and ciprofloxacin ( $5 \mu \mathrm{g} /$ well) was used as positive controls. The antibacterial activity was determined by measuring the diameter of the inhibition zone to the nearest millimeter. 
2.2.7. Determination of Minimum Inhibitory Concentration. The minimum inhibitory concentration (MIC) of the extracts was carried out by using the broth microdilution method [31]. The test was performed using sterile polystyrene 96-well plates. $100 \mu \mathrm{L}$ of autoclaved Mueller-Hinton broth supplemented with different concentrations of the extracts was added to each well. Subsequently, $5 \mu \mathrm{L}$ of the bacteria including Staphylococcus aureus, Bacillus subtilis, Pseudomonas aeruginosa, and Escherichia coli at the concentration of approximately $10^{8} \mathrm{CFU} / \mathrm{mL}$ was added. The plate was shaken and incubated at $37^{\circ} \mathrm{C}$ for $24 \mathrm{~h} .0 .1 \% \mathrm{DMSO}$ was used as a negative control and ciprofloxacin was used as a positive control. MIC was defined as the lowest concentration of the extract at which the microorganisms showed no visible growth.

2.2.8. Statistical Analysis. All the data are presented as the mean \pm standard error (SE). Student's $t$-test was used to determine the statistical significance of group means. All tests were two-sided and $p$ values less than 0.05 were considered statistically significant.

\section{Results}

3.1. Determination of Total Phenolic Content. TPC of different extracts was estimated using Folin-Ciocalteu method. Gallic acid was used as a standard. The results were expressed as microgram of GAE per milligram of the extracts (Table 2). In consequence, many Garcinia extracts showed high TPC. Notably, the ME of G. hopii and G. tinctoria and EAE of G. planchonii and G. tinctoria showed high TPC with the values of $60.1,70.8,61$, and $74.1 \mu \mathrm{g}$ GAE/mg, respectively. Among tested Garcinia species, G. tinctoria exhibited high TPC in both EAE and ME. Conversely, there was low TPC in all extracts of G. fusca, G. gaudichaudii, and G. nigrolineata.

3.2. DPPH Assay. The free radical scavenging of the extracts was estimated using DPPH assay. The results were expressed in percentage values of inhibition of radicals (Figure 1). Both EAE of G. tinctoria and ME of G. nigrolineata comparably scavenged the free radicals with the inhibition of approximately $83.5 \%-87 \%$ ( $\mathrm{IC}_{50}=1.5 \mu \mathrm{g} / \mathrm{mL}$ and $2.5 \mu \mathrm{g} / \mathrm{mL}$, resp.). The EAE of G. planchonii and G. fusca and ME of G. hopii showed comparable scavenging property, approximately $71.45 \%, 68.6 \%$, and $65 \%$, respectively. No obvious inhibition was observed in other extracts. Ascorbic acid was used as a positive control, exhibiting the scavenging of $95 \%$ with the $\mathrm{IC}_{50}$ of $0.78 \mu \mathrm{g} / \mathrm{mL}$.

3.3. Hydroxyl Radical Scavenging Assay. The scavenging of $\mathrm{OH}^{-}$was estimated following the procedure as described by Smirnoff and Cumbes [32]. The present study revealed the high $\mathrm{OH}^{-}$radical scavenging activity of $\mathrm{ME}$ of $\mathrm{G}$. planchonii (98\%) with the $\mathrm{IC}_{50}$ of $178 \mu \mathrm{g} / \mathrm{mL}$, followed by $\mathrm{ME}$ of G. hopii (56\%). Low inhibition was attained in other extracts. Ascorbic acid was used as a positive control which showed the maximum scavenging of $94 \%$ with the $\mathrm{IC}_{50}$ of $5.5 \mu \mathrm{g} / \mathrm{mL}$ (Figure 2).

3.4. Total Antioxidant Capacity Assay. The TAC of the extracts was evaluated using phosphomolybdate assay, measuring the ability of a sample to destroy a free radical by transferring an electron to the latter. Ascorbic acid was used to provide a standard curve and the TAC was expressed as milligram of AAE per gram of the extract. Table 3 indicates the high TAC of G. tinctoria. Particularly, the TAC of ME, EAE, and HE of G. tinctoria was 265.9, 169.8, and $135.6 \mathrm{mg}$ AAE/g extract, respectively. Comparably, the TACs of ME of G. hopii and EAE of G. planchonii were 208.2 and $160.1 \mathrm{mg}$ AAE/g extract, respectively.

3.5. The Antimicrobial Activity. The antimicrobial property of the extracts was evaluated using diffusion Kirby Bauer assay. The diameters of the inhibition zone were described in Table 4. Subsequently, the antimicrobial extracts were screened for MIC using the microdilution method. Table 5 showed that EAE of G. gaudichaudii was effective against Gram-positive bacteria ( $S$. aureus and B. subtilis) with an MIC of approximately $15.625-25 \mu \mathrm{g} / \mathrm{mL}$ whereas $\mathrm{ME}$ of G. planchonii was effective against both Gram-positive bacteria (S. aureus and B. subtilis) $(\mathrm{MIC}=160 \mu \mathrm{g} / \mathrm{mL})$ and Gram-negative bacteria (E. coli, $P$. aeruginosa) $(\mathrm{MIC}=75 \mu \mathrm{g} / \mathrm{mL})$. However, the MICs of both extracts were higher compared to that of ciprofloxacin (MIC $=0.25 \mu \mathrm{g} / \mathrm{mL}$ and $0.016 \mu \mathrm{g} / \mathrm{mL}$ against Gram-positive and Gram-negative bacteria, subsequently).

\section{Discussion}

In this study, we collected six species of Garcinia including G. fusca, G. planchonii, G. hopii, G. tinctoria, G. nigrolineata, and G. gaudichaudii and then extracted them using different solvents, named hexane, ethyl acetate, and methanol. The phytochemicals of the extract relating to polyphenol were measured and the bioactivity including antioxidant and antimicrobial capacity was determined. The results indicated that ME and EAE of G. tinctoria showed promising antioxidant property while EAE of G. gaudichaudii and ME of G. planchonii possessed high antimicrobial activity.

Phenolic compounds are secondary metabolites containing at least one phenol unit in the structure. They are phytochemicals found in many plants which have a function as substances protecting plants from oxidative stress by neutralizing the free radicals by donating hydrogen, reducing and chelating metal, and capturing singlet oxygen [33]. Additionally, these metabolites break the free radical chain reaction by forming a relatively stable phenoxy-radical intermediate [34]. They are antioxidants which are used to treat various diseases relating to oxidative stress including cancer, cardiovascular diseases, Alzheimer's disease, and aging-related diseases $[35,36]$. Therefore, isolating the extracts containing high phenolic compounds is required. In the present study, of the six, G. tinctoria showed the highest TPC (74.1 $\mu \mathrm{g}$ GAE/mg) (Table 2). Compared to HE, ME and 
TABLE 2: The total polyphenolic content of various species of genus Garcinia.

\begin{tabular}{|c|c|c|}
\hline Garcinia species & Extracts & Total polyphenolic content ( $\mu \mathrm{g} \mathrm{QE} / \mathrm{mg}$ extract) \\
\hline \multirow{3}{*}{ G. fusca } & $\mathrm{HE}$ & $20.58 \pm 2.3$ \\
\hline & EAE & $45.18 \pm 4.4$ \\
\hline & ME & $35.17 \pm 2.5$ \\
\hline \multirow{3}{*}{ G. hopii } & $\mathrm{HE}$ & $22.14 \pm 5.1$ \\
\hline & EAE & $20.22 \pm 2.4$ \\
\hline & ME & $60.09 \pm 4.3$ \\
\hline \multirow{3}{*}{ G. planchonii } & $\mathrm{HE}$ & $39.53 \pm 2.5$ \\
\hline & EAE & $60.99 \pm 5.6$ \\
\hline & $\mathrm{ME}$ & $17.16 \pm 2.1$ \\
\hline \multirow{3}{*}{ G. nigrolineata } & $\mathrm{HE}$ & $17.89 \pm 2.5$ \\
\hline & EAE & $34.78 \pm 3.4$ \\
\hline & $\mathrm{ME}$ & $29.99 \pm 2.4$ \\
\hline \multirow{3}{*}{ G. gaudichaudii } & $\mathrm{HE}$ & $12.34 \pm 1.5$ \\
\hline & EAE & $41.59 \pm 4.3$ \\
\hline & $\mathrm{ME}$ & $15.76 \pm 3.4$ \\
\hline \multirow{3}{*}{ G. tinctoria } & $\mathrm{HE}$ & $27.79 \pm 3.8$ \\
\hline & EAE & $74.12 \pm 4.9$ \\
\hline & $\mathrm{ME}$ & $70.84 \pm 3.6$ \\
\hline
\end{tabular}
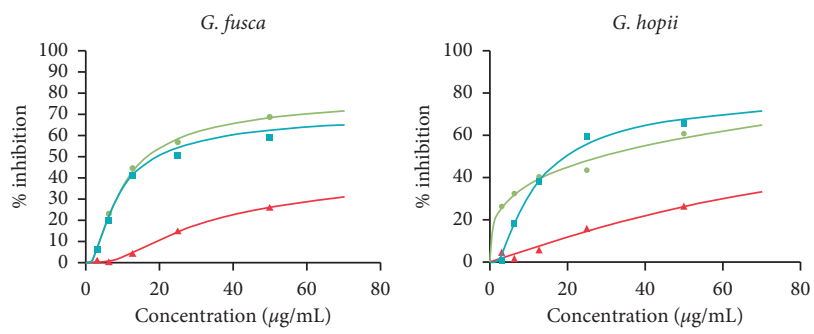

$\triangle$ Hexane

- Ethyl acetate

- Methanol

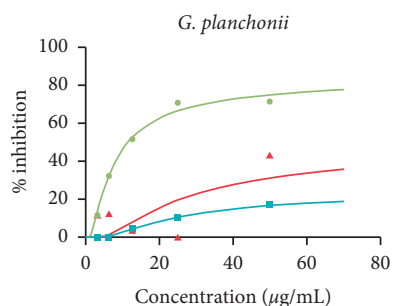

$\triangle$ Hexane

- Ethyl acetate

- Methanol

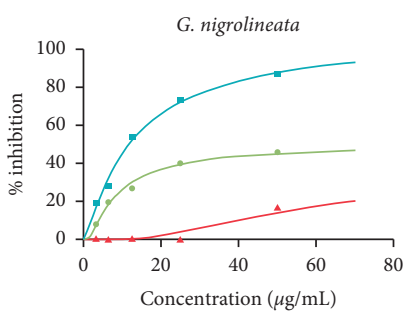

$\triangle$ Hexane

- Ethyl acetate

- Methanol

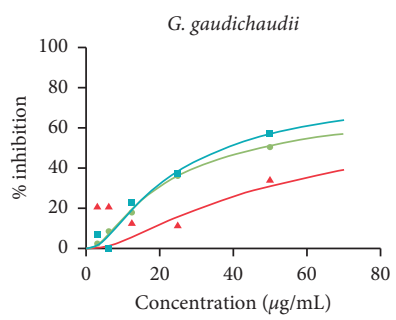

- Ethyl acetate

- Methanol
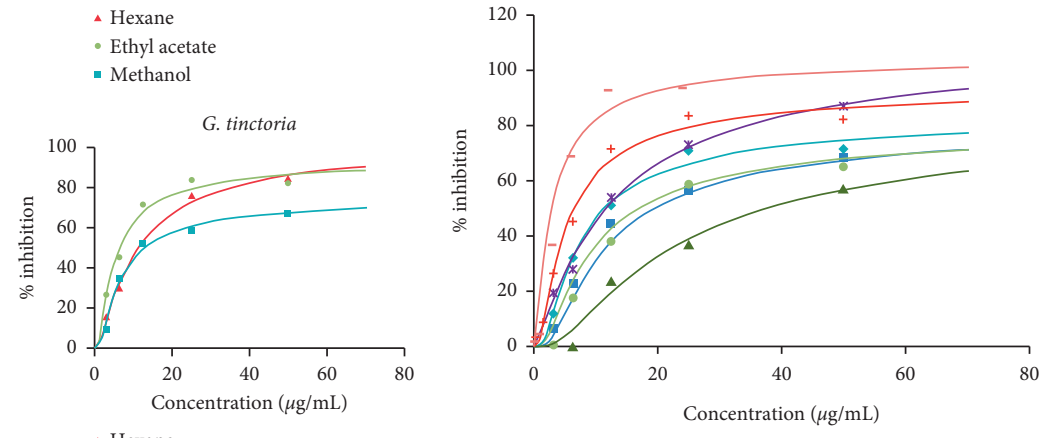

$\triangle$ Hexane

- Ethyl acetate

$\Delta$ Hexane

- Ethyl acetate

- Methanol

$$
\begin{array}{ll}
\text { - EAE of G. fusca } & \text { A ME of G. gaudichaudii } \\
\text { - ME of G. hopii } & + \text { EAE of G. tinctoria } \\
\text { - EAE of G. planchonii } & \text { - Ascorbic acid } \\
\text { * ME of G. nigrolineata } &
\end{array}
$$

(a)

(b)

FIGURE 1: The free radical scavenging capability of extracts of Garcinia species using DPPH assay. (a) The activities of various extracts. (b) The activities of different species. The extracts were supplemented with DPPH (dissolved in methanol), then shaken vigorously, and incubated in dark at room temperature for 30 mins. Subsequently, the absorbance was measured at $517 \mathrm{~nm}$ using a spectrophotometer. Ascorbic acid was used as a positive control and $0.1 \mathrm{mM} \mathrm{DMSO}$ was used as a negative control. The most bioactive extract of each species was chosen to compare with others. 


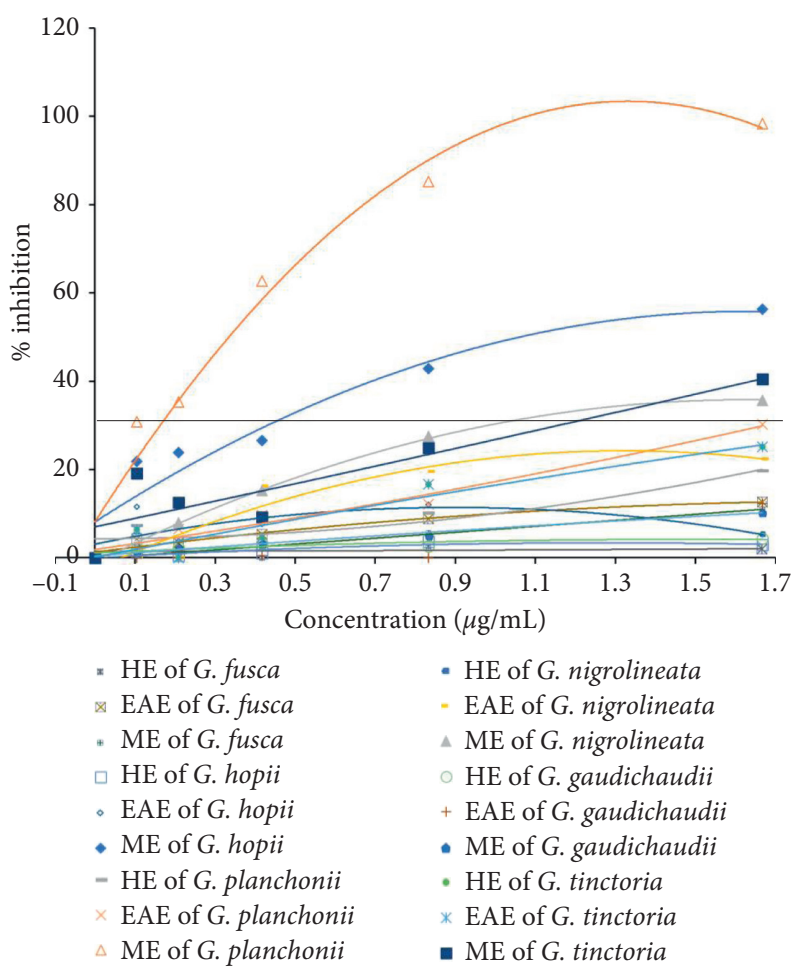

Figure 2: The hydroxyl radical scavenging capability of extracts of different Garcinia species. The extracts were supplemented with $\mathrm{FeSO}_{4} .7 \mathrm{H}_{2} \mathrm{O}$, salicylic acid, and $\mathrm{H}_{2} \mathrm{O}_{2}$, followed by being mixed and incubated at $37^{\circ} \mathrm{C}$ for 30 mins before applied onto a spectrophotometer to measure the absorbance at $562 \mathrm{~nm}$. Ascorbic acid was used as a positive control and $0.1 \mathrm{mM}$ DMSO was used as a negative control.

Table 3: The total antioxidant capacity of the extracts of different Garcinia species.

\begin{tabular}{|c|c|c|}
\hline Garcinia species & Extracts & Total antioxidant capacity (mg AAE/g extract) \\
\hline \multirow{3}{*}{ G. fusca } & $\mathrm{HE}$ & 0 \\
\hline & EAE & $130.16 \pm 5.3$ \\
\hline & $\mathrm{ME}$ & $34.56 \pm 2.1$ \\
\hline \multirow{3}{*}{ G. hopii } & $\mathrm{HE}$ & $2.57 \pm 0.5$ \\
\hline & EAE & $91.77 \pm 2.4$ \\
\hline & $\mathrm{ME}$ & $209.22 \pm 7.5$ \\
\hline \multirow{3}{*}{ G. planchonii } & $\mathrm{HE}$ & 0 \\
\hline & EAE & $160.16 \pm 5.5$ \\
\hline & $\mathrm{ME}$ & $35.08 \pm 6.3$ \\
\hline \multirow{3}{*}{ G. nigrolineata } & $\mathrm{HE}$ & $5.43 \pm 1.2$ \\
\hline & EAE & $111.13 \pm 4.5$ \\
\hline & $\mathrm{ME}$ & $87.26 \pm 8.2$ \\
\hline \multirow{3}{*}{ G. gaudichaudii } & $\mathrm{HE}$ & $4.35 \pm 1.2$ \\
\hline & EAE & $70.48 \pm 5.4$ \\
\hline & $\mathrm{ME}$ & $76.29 \pm 7.3$ \\
\hline \multirow{3}{*}{ G. tinctoria } & $\mathrm{HE}$ & $135.65 \pm 8.4$ \\
\hline & EAE & $169.84 \pm 4.5$ \\
\hline & $\mathrm{ME}$ & $265.97 \pm 9.4$ \\
\hline
\end{tabular}

EAE possessed higher TPC. The difference in solvent polarity determines the components in the extracts. The high polarity (methanol) and medium polarity (ethyl acetate) solvents enabled the isolation of more effective polyphenol compounds. Previous studies revealed the capacity of ethyl acetate and methanol in the extraction of high bioactive compounds [37-39]. Therefore, the choice of a suitable solvent is important in the isolation of natural extracts or compounds.

The DPPH assay is a frequently used technique to determine the radical scavenging capacity of plant-based extracts because of its quick and responsive features, which involve simple conventional laboratory equipment. The results showed that $\mathrm{ME}$ and EAE exhibited higher free 
TABLE 4: The inhibition zone diameter of extracts of different Garcinia species on bacterial strains.

\begin{tabular}{|c|c|c|c|c|c|}
\hline \multirow{2}{*}{ Garcinia species } & \multirow{2}{*}{ Extracts } & \multicolumn{4}{|c|}{ Inhibition zone diameter (mm) } \\
\hline & & S. aureus & B. subtilis & P. aeruginosa & E. coli \\
\hline \multirow[t]{2}{*}{ Ciprofloxacin } & & 17 & 15 & 23 & 32 \\
\hline & $\mathrm{HE}$ & 8 & - & 8 & - \\
\hline \multirow{3}{*}{ G. fusca } & EAE & $12.5 \pm 2.5$ & $11 \pm 2.3$ & $8.5 \pm 1.5$ & - \\
\hline & ME & - & - & - & - \\
\hline & $\mathrm{HE}$ & - & - & - & - \\
\hline \multirow[t]{2}{*}{ G. hopii } & EAE & $9 \pm 1.2$ & - & $9 \pm 1.3$ & - \\
\hline & $\mathrm{ME}$ & $10.5 \pm 2.3$ & - & $7 \pm 1$ & - \\
\hline \multirow{3}{*}{ G. planchonii } & $\mathrm{HE}$ & $8 \pm 1.4$ & - & $8 \pm 1.5$ & - \\
\hline & EAE & $12 \pm 1.7$ & - & - & - \\
\hline & $\mathrm{ME}$ & $17 \pm 2.5$ & $16 \pm 1.2$ & $15 \pm 1.5$ & $20 \pm 1.2$ \\
\hline \multirow{3}{*}{ G. nigrolineata } & $\mathrm{HE}$ & - & - & - & - \\
\hline & EAE & $9 \pm 1.3$ & - & $9 \pm 1.8$ & $8 \pm 1.4$ \\
\hline & ME & - & - & $9 \pm 1.4$ & - \\
\hline \multirow{3}{*}{ G. gaudichaudii } & $\mathrm{HE}$ & - & - & - & - \\
\hline & EAE & $17 \pm 1$ & $14 \pm 0.7$ & $7.5 \pm 1.5$ & - \\
\hline & $\mathrm{ME}$ & $8 \pm 1.7$ & - & $8 \pm 2.3$ & - \\
\hline \multirow{3}{*}{ G. tinctoria } & $\mathrm{HE}$ & $10 \pm 2.1$ & - & - & - \\
\hline & EAE & $12 \pm 1.9$ & - & - & - \\
\hline & $\mathrm{ME}$ & $10 \pm 0.9$ & - & - & - \\
\hline
\end{tabular}

TABle 5: The MICs of extracts of different Garcinia species on bacterial strains.

\begin{tabular}{lcccc}
\hline \multirow{2}{*}{ The extracts } & \multicolumn{3}{c}{ MICs on bacterial strains $(\mu \mathrm{g} / \mathrm{mL})$} \\
& S. aureus & B. subtilis & E. coli & 0.016 \\
Ciprofloxacin & 0.25 & 0.25 & 100 & P. aeruginosa \\
EAE of G. fusca & 120 & 50 & 200 & 10016 \\
ME of G. hopii & 140 & 200 & 75 & 100 \\
ME of G. planchonii & 160 & 160 & 100 \\
EAE of G. gaudichaudii & 15.625 & 25 & 75 \\
\hline
\end{tabular}

radical scavenging ability compared to HE. Among them, EAE of $G$. tinctoria possessed the strongest free radical scavenging capacity with the inhibition of approximately $83.5 \%$ at $\mathrm{IC}_{50}$ of $1.5 \mu \mathrm{g} / \mathrm{mL}$ (Figure 2). The TPC results were in accordance with the antioxidant activity determined by DPPH and TAC assays (Table 2, Figure 1) which demonstrated that the antioxidant activity of $G$. tinctoria was mainly due to hampering free radicals of phenolic compounds in the extract. Many studies mentioned effective free radical inhibition of the phenolic-rich extraction [40-42]. However, the polyphenol content was not in accordance with the hydroxyl scavenging capacity (Table 2 and Figure 2). In particular, ME of $G$. planchonii showed the strongest hydroxyl scavenging activity with low polyphenol content (approximately 17.16 $\mu \mathrm{g}$ GAE/mg). Therefore, other compounds might contribute to this activity of the extract.

In terms of antimicrobial activity, ME of $G$. planchonii arrested the growth of both Gram-positive and Gramnegative bacterial strains while EAE of G. gaudichaudii hampered the proliferation of Gram-positive bacteria (Tables 4 and 5). However, the activities of both extracts were lower compared to those of ciprofloxacin (positive control). The poorer activity may be due to the interference with the active compounds of other components in the extract.
Mostly the extracts or compounds target Gram-positive strains better than Gram-negative strains. The difference might be explained by the distinction in the structure of peptidoglycan, presence of outer membrane, receptors or lipids, cross-linking, and the activity of autolytic enzymes that determine the penetration, binding, and action of the compounds [43]. A study by Sunitha Janardhanan et al. demonstrated that crude chloroform extract of G. mangostana pericarp effectively inhibited Gram-positive bacteria including Streptococcus mutans, Streptococcus sanguis, Streptococcus salivarius, Streptococcus oralis, and Lactobacillus acidophilus [44]. Besides, other natural extracts or compounds also exhibited a higher sensitivity to Grampositive bacteria [45-47].

\section{Conclusions}

This study was conducted by extracting different Garcinia species grown in Vietnam using various solvents. The total polyphenol content and bioactivity including antioxidant and antimicrobial activities were evaluated. Our results demonstrated that the EAE of G. tinctoria showed promising antioxidant capacity. In the antimicrobial assays, ME of G. planchonii was efficient against both Gram-positive 
bacteria (S. aureus and B. subtilis) (MIC $=160 \mu \mathrm{g} / \mathrm{mL})$ and Gram-negative bacteria (E. coli, $P$. aeruginosa) $(\mathrm{MIC}=75 \mu \mathrm{g} / \mathrm{mL})$ while EAE of $G$. gaudichaudii was effective against Gram-positive bacteria ( $S$. aureus and B. subtilis) with the MIC of approximately $15.625-25 \mu \mathrm{g} / \mathrm{mL}$. Taken together, our results elucidated the antioxidation and antimicrobial property of several Garcinia extracts.

\section{Abbreviations}

$\begin{array}{ll}\text { DPPH: } & \text { 2, 2-Diphenyl-1-picrylhydrazyl } \\ \text { IC }_{50}: & \text { Half-maximal inhibitory concentration } \\ \text { MIC: } & \text { Minimal inhibition concentration } \\ \text { VNU- } & \text { Vietnam National University-Ho Chi Minh } \\ \text { HCM: } & \text { City } \\ \text { DMSO: } & \text { Dimethyl sulfoxide } \\ \text { HE: } & \text {-Hexane extract } \\ \text { EAE: } & \text { Ethyl acetate extract } \\ \text { ME: } & \text { Methanol extract } \\ \text { GAE: } & \text { Gallic acid equivalent } \\ \text { TAC: } & \text { Total antioxidant capacity } \\ \text { AAE: } & \text { Ascorbic acid equivalent } \\ \text { SE: } & \text { Standard error } \\ \text { TPC: } & \text { The polyphenolic content. }\end{array}$

\section{Data Availability}

The datasets used and/or analyzed during the current study are available from the corresponding author on reasonable request.

\section{Conflicts of Interest}

The authors declare that there are no conflicts of interest regarding the publication of this article.

\section{References}

[1] B. Biloa Messi, R. Ho, A. Meli Lannang et al., "Isolation and biological activity of compounds from Garcinia preussii," Pharmaceutical Biology, vol. 52, no. 6, pp. 706-711, 2014.

[2] I. Onakpoya, S. K. Hung, R. Perry, B. Wider, and E. Ernst, "The use of garcinia extract (hydroxycitric acid) as a weight loss supplement: a systematic review and meta-analysis of randomised clinical trials," Journal of Obesity, vol. 2011, Article ID 509038, 9 pages, 2011.

[3] K. Hayamizu, Y. Ishii, I. Kaneko et al., "Effects of Garcinia cambogia (hydroxycitric acid) on visceral fat accumulation: a double-blind, randomized, placebo-controlled trial," Current Therapeutic Research, Clinical and Experimental, vol. 64, 2003.

[4] R. Sripradha and S. G. Magadi, "Efficacy of Garcinia Cambogia on body weight, inflammation and glucose tolerance in high fat fed male wistar rats," Journal of Clinical and Diagnostic Research, vol. 9, no. 2, pp. BF01-BF04, 2015.

[5] A. Subarnas, A. Diantini, R. Abdulah et al., "Apoptosis-mediated antiproliferative activity of friedolanostane triterpenoid isolated from the leaves of Garcinia celebica against MCF-7 human breast cancer cell lines," Biomed Reports, vol. 4, no. 1, pp. 79-82, 2016.

[6] A. Raksat, W. Maneerat, R. J. Andersen, S. G. Pyne, and S. Laphookhieo, "A tocotrienol quinone dimer and xanthones from the leaf extract of Garcinia nigrolineata," Fitoterapia, vol. 136, Article ID 104175, 2019.

[7] I. Dhamija, M. Parle, and S. Kumar, "Antidepressant and anxiolytic effects of Garcinia indica fruit rind via monoaminergic pathway," 3 Biotech, vol. 7, no. 2, p. 131, 2017.

[8] I. Meechai, W. Phupong, W. Chunglok, and P. Meepowpan, "Antioxidant properties and phytochemical contents of Garcinia schomburgkiana Pierre," Journal of Applied Pharmaceutical Science, vol. 6, 2016.

[9] R. Abdulah, E. W. Suradji, A. Subarnas et al., "Catechin isolated from Garcinia celebica leaves inhibit Plasmodium falciparum growth through the induction of oxidative stress," Pharmacognosy Magazine, vol. 13, 2017.

[10] N. K. Nguyen, X. A. Truong, T. Q. Bui et al., " $\alpha$-Glucosidase inhibitory xanthones from the roots of Garcinia fusca," Chemistry Biodiversity, vol. 14, 2017.

[11] V. Rukachaisirikul, K. Tadpetch, A. Watthanaphanit, N. Saengsanae, and S. Phongpaichit, "Benzopyran, biphenyl, and tetraoxygenated xanthone derivatives from the twigs of Garcinia nigrolineata," Journal of Natural Products, vol. 68, no. 8, 2005.

[12] V. Rukachaisirikul, M. Kamkaew, D. Sukavisit, S. Phongpaichit, P. Sawangchote, and W. C. Taylor, "Antibacterial xanthones from the leaves of Garcinia nigrolineata," Journal of Natural Products, vol. 66, no. 12, 2003.

[13] V. Panda, H. Ashar, and S. Srinath, "Antioxidant and hepatoprotective effect of Garcinia indica fruit rind in ethanolinduced hepatic damage in rodents," Interdisciplinary Toxicology, vol. 5, no. 4, 2012.

[14] B. Uttara, A. Singh, P. Zamboni, and R. Mahajan, "Oxidative stress and neurodegenerative diseases: a review of upstream and downstream antioxidant therapeutic options," Current Neuropharmacology, vol. 7, no. 1, 2009.

[15] I. Liguori, G. Russo, F. Curcio et al., "Oxidative stress, aging, and diseases," Clinical Interventions in Aging, vol. 13, pp. 757-772, 2018.

[16] S. B. Nimse and D. Pal, "Free radicals, natural antioxidants, and their reaction mechanisms," RSC Advances, vol. 5, no. 35, 2015.

[17] V. Lobo, A. Patil, A. Phatak, and N. Chandra, "Free radicals, antioxidants and functional foods: impact on human health," Pharmacognosy Reviews, vol. 4, no. 8, 2010.

[18] W. N. Tan, M. Khairuddean, K. C. Wong, W. Y. Tong, and D. Ibrahim, "Antioxidant compounds from the stem bark of Garcinia atroviridis," Journal of Asian Natural Products Research, vol. 18, 2016.

[19] R. Sripradha, M. G. Sridhar, and N. Maithilikarpagaselvi, "Antihyperlipidemic and antioxidant activities of the ethanolic extract of Garcinia cambogia on high fat diet-fed rats," Journal of Complementary and Integrative Medicine, vol. 13, 2016.

[20] N. A. Mohammad, D. N. Abang Zaidel, I. I. Muhamad, M. Abdul Hamid, H. Yaakob, and Y. M. Mohd Jusoh, "Optimization of the antioxidant-rich xanthone extract from mangosteen (Garcinia mangostana L.) pericarp via microwave-assisted extraction," Heliyon, vol. 5, 2019.

[21] W. Suttirak and S. Manurakchinakorn, "In vitro antioxidant properties of mangosteen peel extract," Journal of Food Science and Technology, vol. 1, no. 12, pp. 3546-3458, 2014.

[22] S. Manandhar, S. Luitel, and R. K Dahal, "In vitro antimicrobial activity of some medicinal plants against human pathogenic bacteria," Journal of Tropical Medicine, vol. 2019, Article ID 1895340, , 2019.

[23] N. M. Atef, S. M. Shanab, S. I. Negm, and Y. A. Abbas, "Evaluation of antimicrobial activity of some plant extracts 
against antibiotic susceptible and resistant bacterial strains causing wound infection," Bulletin of the National Research Centre, vol. 43, 2019.

[24] M. M. Cowan, "Plant products as antimicrobial agents," Clinical Microbiology Reviews, vol. 12, 1999.

[25] C. Tharachand, C. Immanuel Selvaraj, and Z. Abraham, "Comparative evaluation of anthelmintic and antibacterial activities in leaves and fruits of Garcinia cambogia (gaertn.) desr. and Garcinia indica (dupetit-thouars) choisy," Brazilian Archives of Biology and Technology, vol. 58, no. 3, 2015.

[26] R. L. Sutar, S. P. Mane, and J. S. Ghosh, "Antimicrobial activity of extracts of dried Kokum (Garcinia indica C.)," International Food Research Journal, vol. 19, no. 3, 2012.

[27] V. L. Singleton, R. Orthofer, and R. M. Lamuela-Raventós, "Analysis of total phenols and other oxidation substrates and antioxidants by means of folin-ciocalteu reagent," Methods in Enzymology, vol. 299, 1999.

[28] Q. Shen, B. Zhang, R. Xu, Y. Wang, X. Ding, and P. Li, "Antioxidant activity in vitro of the selenium-contained protein from the se-enriched bifidobacterium animalis 01," Anaerobe, vol. 16, no. 4, 2010.

[29] S. M. Klein, G. Cohen, and A. I. Cederbaum, "Production of formaldehyde during metabolism of dimethyl sulfoxide by hydroxyl radical generating systems," Biochemistry, vol. 20, 1981.

[30] C. Wan, Y. Yu, S. Zhou, W. Liu, S. Tian, and S. Cao, "Antioxidant activity and free radical-scavenging capacity of Gynura divaricata leaf extracts at different temperatures," Pharmacognosy Magazine, vol. 7, no. 25, 2011.

[31] J. J. Biemer, "Antimicrobial susceptibility testing by the KirbyBauer disc diffusion method," Annals of Clinical Laboratory Science, vol. 3, no. 2, 1973.

[32] N. Smirnoff and Q. J. Cumbes, "Hydroxyl radical scavenging activity of compatible solutes," Phytochemistry, vol. 28, 1989.

[33] C. A. Rice-Evans, N. J. Miller, and G. Paganga, "Antioxidant properties of phenolic compounds," Trends in Plant Science, vol. 2, no. 4, 1997.

[34] S. Mathew, T. E. Abraham, and Z. A. Zakaria, "Reactivity of phenolic compounds towards free radicals under in vitro conditions," Journal of Food Science and Technology, vol. 52, no. 9, 2015.

[35] K. B. Pandey and S. I. Rizvi, "Plant polyphenols as dietary antioxidants in human health and disease," Oxidative Medicine and Cellular Longevity, vol. 2, no. 5, 2009.

[36] C. Forni, F. Facchiano, M. Bartoli et al., "Beneficial role of phytochemicals on oxidative stress and age-related diseases," BioMed Research International, vol. 2019, Article ID 8748253, 16 pages, 2019.

[37] D. Pintać, T. Majkić, L. Torović et al., "Solvent selection for efficient extraction of bioactive compounds from grape pomace," Industrial Crops and Products, vol. 111, 2018.

[38] B. H. Do, N. S. Hoang, T. P. T. Nguyen, N. Q. C. Ho, T. L. Le, and C. C. Doan, "Phenolic extraction of Moringa Oleifera leaves induces caspase-dependent and caspase-independent apoptosis through the generation of reactive oxygen species and the activation of intrinsic mitochondrial pathway in human melanoma cells," Nutrition and Cancer, vol. 73, no. 5, pp. 869-888, 2020.

[39] R. A. Laeliocattleya, "The potential of methanol and ethyl acetate extracts of corn silk (Zea mays L.) as sunscreen," AIP Conference Proceedings, vol. 2099, 2019.

[40] J. Li, R. Abel, K. Zhu, Y. Cao, S. Zhao, and R. A. Friesner, "The VSGB 2.0 model: a next generation energy model for high resolution protein structure modeling," Proteins Structure, Function, and Bioinformatics, vol. 79, 2011.
[41] M. Gangwar, M. K. Gautam, A. K. Sharma, Y. B. Tripathi, R. K. Goel, and G. Nath, "Antioxidant capacity and radical scavenging effect of polyphenol rich Mallotus philippenensis fruit extract on human erythrocytes: an in vitro study," Scientific World Journal, vol. 2014, Article ID 279451, 2014.

[42] A. Morabbi Najafabad and R. Jamei, "Free radical scavenging capacity and antioxidant activity of methanolic and ethanolic extracts of plum (Prunus domestica L.) in both fresh and dried samples," Avicenna Journal of Phytomedicine, vol. 4, no. 5, 2014.

[43] Z. Breijyeh, B. Jubeh, and R. Karaman, "Resistance of gramnegative bacteria to current antibacterial agents and approaches to resolve it," Molecules, vol. 25, no. 6, 2020.

[44] S. Janardhan, J. Mahendra, A. S. S. Girija, L. Mahendra, and V. Priyadharsini, "Antimicrobial effects of Garcinia mangostana on cariogenic microorganisms," Journal of Clinical and Diagnostic Research, vol. 11, 2017.

[45] A. M. Amer, "Antimicrobial effects of egyptian local chicory, cichorium endivia subsp. pumilum," International Journal of Microbiology, vol. 2018, Article ID 6475072, 6 pages, 2018.

[46] H. Koohsari, E. A. Ghaemi, M. Sadegh Sheshpoli, M. Jahedi, and M. Zahiri, "The investigation of antibacterial activity of selected native plants from North of Iran," Journal of Medicine and Life, vol. 8, 2015.

[47] W. A. Hussin and W. M. El-Sayed, "Synergic interactions between selected botanical extracts and tetracycline against gram positive and gram negative bacteria," Journal of Biological Sciences, vol. 11, no. 7, 2011. 